\title{
Mineral Analysis of Milk through Atomic Absorption Spectroscopy and Their Biological Role in Human Life
}

\author{
Mehar Ali. Kazi
}

\begin{abstract}
Milk is essential human diet because it contains many essential trace minerals such as Calcium, Magnesium, Copper, Zinc, Sodium, Potassium and Phosphorous. Utilization of, milk is increasing at large scale through the world. It is essential to maintain the good quality of milk during production and manufacturing because presence of toxic metals in the milk becomes cause of health disturbance in human life. Many researchers identified the availability of heavy metals in the milk and it is necessary to know the level of heavy metal in the milk because of high utilization by infants and children's. The purpose of this research study is to analyze the presence of major and minor minerals in different milk samples. Flame Atomic Absorption Spectroscopy was used in the analysis of minerals
\end{abstract}

Keywords- Milk, Minerals, Flame Atomic Absorption Spectroscopy.

\section{INTRODUCTION}

$\mathrm{T}$ HE milk is best diet for human health because it contains a good source of essential minerals such as calcium and phosphorous [1-3]. Due to the nutritional importance milk is consumed at large scale in recent time. Dairy products now days are considered as good source of nutrients for human health throughout the world [4-5]. Milk is also considered as raw material formed by animals [6-7]. Milk production should be controlled in the light of its component not only for protein and fats but also in the terms of mineral contents whenever possible. Milk is the best source of calcium and it can also provide some concentration of magnesium, zinc and some level of iron and copper [8-10]. Presence of phosphorous in the milk is essential for controlling acid base balance, energy metabolism and also organizes the cell membrane structure. Phosphorous works collaboratly with milk calcium and sustain the hardness of bones and teeth. To investigate the quality of food it is necessary to determine the concentration of trace metal contents such as calcium, phosphorous, magnesium, copper, iron and zinc etc. for analysis of these metals various techniques are applied like flame atomic absorption spectrophotometry, capillary zone electrophoresis. Many researchers identified the availability of heavy metals in the milk and it is essential to know the level of heavy metals in the milk because of high utilization by infants and children [11].

\section{EXPERIMENTAL}

\section{A. Reagent and Solution}

All reagents were used of analytical grade (E. Merk). Deionized water was used for the preparation of all the solutions. All glassware were first cleaned with detergent and distilled water, and then rinsed several times with de-ionized water. All glassware was left for dried for some time. All working standard solutions were prepared by diluting stock solution.

\section{B. Sampling}

Five different samples of milk were collected from Hyderabad super market and then samples were prepared for analysis on atomic absorption in nutritional research lab institute of biochemistry, University of Sindh, Jamshoro. These samples belong to different companies such as Tea Max (Haleeb Foods), Tarang (engro Foods), Milk-Pak (Nestle), City Sample, Village Sample.

\section{C.Sample preparation}

Take $5 \mathrm{ml}$. of each milk sample in the volumetric flask as shown in Figure 1 and add 50ml. of 24\% TCA for the digestion of milk sample. Quantities Shown in Table 1 and the digested samples are shown in Figure 1 Shake the samples at 5 minutes interval for 30 minutes, and then centrifuge each sample for 5 minutes at $4000 \mathrm{rpm}$. Filter each sample with filter paper and preserved the filtrate in the stopper bottle then forward it for the Atomic Absorption analysis (shown in figure 2.3). 
TABLE I

QUANTITY FOR THE DIGESTION OF MILK

\begin{tabular}{lcc}
\hline \hline \multicolumn{1}{c}{ Milk Sample } & $\begin{array}{c}\text { Quantity } \\
(\mathrm{mL})\end{array}$ & Amount of TCA (mL) \\
\hline Tea Max & 5 & 50 \\
Tarang & 5 & 50 \\
Milk-pak & 5 & 50 \\
City sample (Hyd) & 5 & 50 \\
Village Sample & 5 & 50 \\
\hline \hline
\end{tabular}

Fig.1. Milk samples in the volumetric Flask

\section{RESULTS AND DISCUSSION}

After the digestion of the samples, finally for the analysis samples were applied on Atomic absorption.. Before of the samples run on Atomic absorption, different parameters of A.A were settled like; Temperature and Pressure. Temperature was settled at the range of $2500{ }^{\circ} \mathrm{C}$ and Pressure of air at the range of 6Psi and the Pressure of Acetylene is 2Psi. After the settlement of parameters, standards of different ppm for every sample were applied first. After the standards, different digested samples of different ranges applied for analysis of the different minerals. Every sample gave different concentration of minerals one by one. The results obtained after analysis are given below in the concentration of ppm and milligram per deciliter $(\mathrm{mg} / \mathrm{dl})$.

TABLE II

CONCENTRATION OF CALCIUM IN MILK SAMPLES

\begin{tabular}{cccc}
\hline \hline Milk samples & Result in Ppm & $\begin{array}{c}\text { Result in } \\
\mathrm{mg} / \mathrm{dl}\end{array}$ & $\begin{array}{c}\text { Nutritional } \\
\text { Normal Range }\end{array}$ \\
\hline Tea Max & 38.45 & 76.9 & $1300 \mathrm{mg} /$ day \\
Milk $-\mathrm{Pak}$ & 29 & 58 & $1300 \mathrm{mg} /$ day \\
Tarang & 24.6 & 49.2 & $1300 \mathrm{mg} /$ day \\
City & 40.36 & 80.72 & $1300 \mathrm{mg} /$ day \\
$\begin{array}{c}\text { Sample(Hyd) } \\
\text { Village }\end{array}$ & 20.6 & 41.2 & $1300 \mathrm{mg} /$ day \\
Sample(umerkot) & &
\end{tabular}

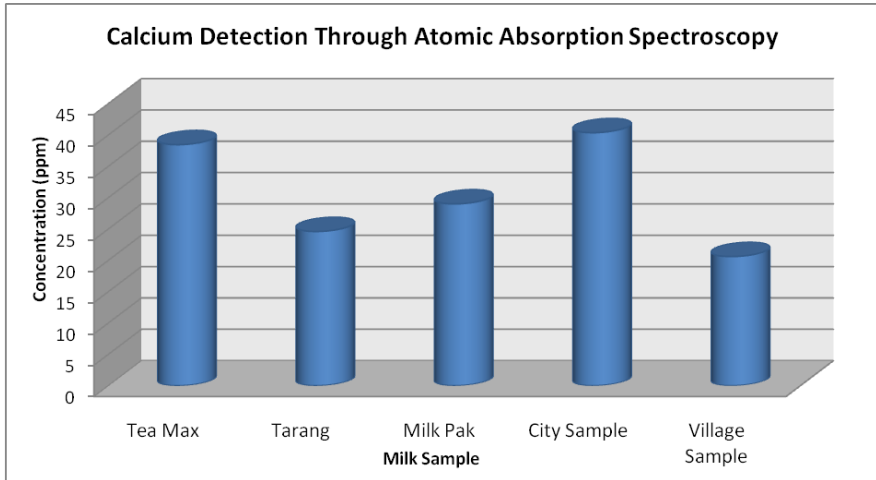

Fig.2. Graph of Calcium (Ca) Concentration shown in different Milk samples

TABLE III

CONCENTRATION OF COPPER IN MILK SAMPLES

\begin{tabular}{cccc}
\hline \hline Milk samples & Result in Ppm & $\begin{array}{c}\text { Result in } \\
\mathrm{mg} / \mathrm{dl}\end{array}$ & $\begin{array}{c}\text { Nutritional } \\
\text { Normal Range }\end{array}$ \\
\hline Tea Max & 0.012 & 0.024 & $0.9-1.3 \mathrm{mg} / \mathrm{day}$ \\
Milk -Pak & 0.007 & 0.014 & $0.9-1.3 \mathrm{mg} / \mathrm{day}$ \\
Tarang & 0.009 & 0.018 & $0.9-1.3 \mathrm{mg} / \mathrm{day}$ \\
$\begin{array}{c}\text { City } \\
\text { Sample(Hyd) } \\
\text { Village }\end{array}$ & 0.008 & 0.016 & $0.9-1.3 \mathrm{mg} / \mathrm{day}$ \\
Sample(umerkot) & 0.007 & 0.014 & $0.9-1.3 \mathrm{mg} / \mathrm{day}$ \\
\hline \hline
\end{tabular}

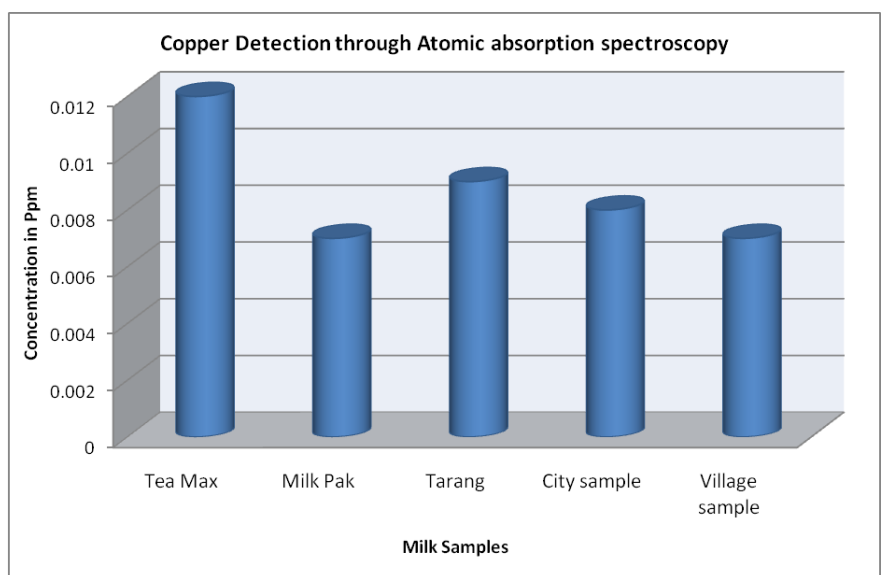

Fig. 3. Graph of Copper $(\mathrm{Cu})$ Concentration shown in different Milk samples

TABLE IV

CONCENTRATION OF LEAD IN MILK SAMPLES

\begin{tabular}{cccc}
\hline \hline Milk samples & Result in Ppm & $\begin{array}{c}\text { Result } \\
\text { in } \\
\mathrm{mg} / \mathrm{dl}\end{array}$ & $\begin{array}{c}\text { Nutritional Normal } \\
\text { Range }\end{array}$ \\
\hline Tea Max & 1.270 & 2.54 & $4-5$ microgram $/ \mathrm{kg} / \mathrm{day}$ \\
Milk -Pak & 0.725 & 1.45 & $4-5$ microgram $/ \mathrm{kg} / \mathrm{day}$ \\
Tarang & 0.816 & 1.632 & $4-5$ microgram $/ \mathrm{kg} / \mathrm{day}$ \\
City Sample(Hyd) & 0.698 & 1.396 & $4-5 \mathrm{microgram} / \mathrm{kg} / \mathrm{day}$ \\
Village & 1.38 & 2.76 & $4-5$ microgram $/ \mathrm{kg} / \mathrm{day}$ \\
Sample(umerkot) & & & \\
\hline \hline
\end{tabular}




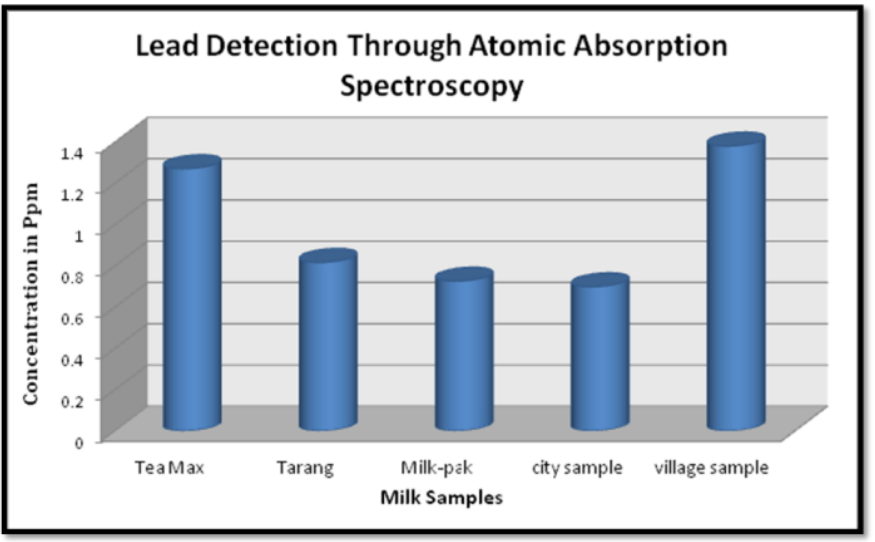

Fig. 4. Graph of Lead $(\mathrm{Pb})$ Concentration shown in different Milk samples

TABLE V

CONCENTRATION OF LEAD IN MILK SAMPLES

\begin{tabular}{cc}
\hline \hline Milk samples & Results \\
\hline Tea Max & Not detectable \\
Milk $-\mathrm{Pak}$ & Not detectable \\
Tarang & Not detectable \\
City Sample(Hyd) & Not detectable \\
Village Sample(umerkot) & Not detectable \\
\hline \hline
\end{tabular}

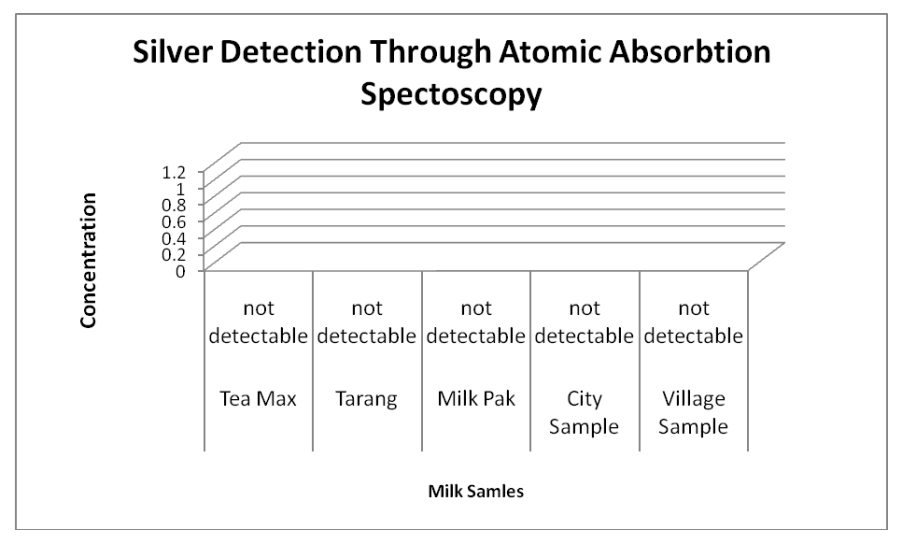

Fig.5. Graph of Silver (Ag) Concentration shown in different Milk samples

TABLE 3.5

TABLE.3.5. COMPARISON AMONG DETECTED MINERALS FROM THE SAMPLES

\begin{tabular}{ccccc}
\hline \hline $\begin{array}{c}\text { Milk } \\
\text { Samples }\end{array}$ & $\begin{array}{c}\text { Calcium(Ca) } \\
\text { in }\end{array}$ & $\begin{array}{c}\text { Copper(cu) } \\
\text { in ppm }\end{array}$ & $\begin{array}{c}\text { Lead (Pb) } \\
\text { in ppm }\end{array}$ & $\begin{array}{c}\text { Silver (Ag) } \\
\text { in Ppm }\end{array}$ \\
\hline Tea Max & 38.45 & 0.012 & 1.27 & 0 \\
Milk-pak & 24.6 & 0.009 & 0.816 & 0 \\
Tarang & 29 & 0.007 & 0.725 & 0 \\
City Sample & 40.36 & 0.008 & 0.698 & 0 \\
Village & 20.6 & 0.007 & 1.38 & 0 \\
sample & & &
\end{tabular}

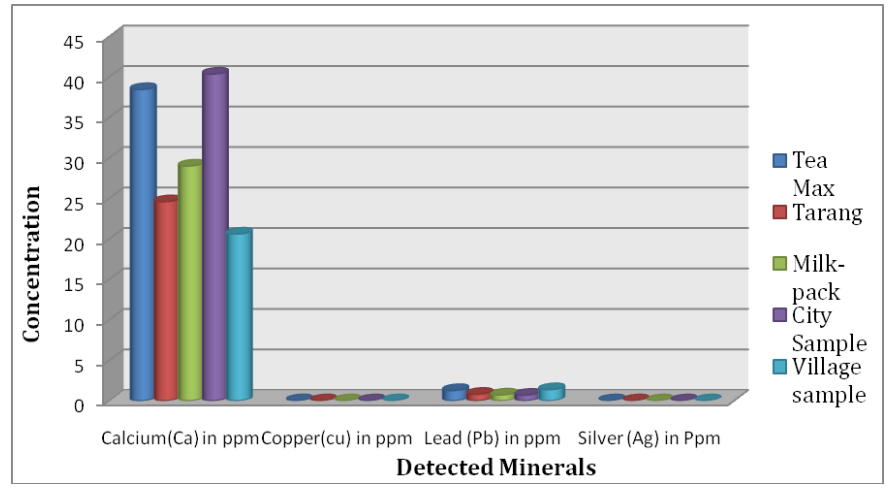

Fig.3.6. Comparison graph of detected Minerals from the samples

\section{REFERENCES}

[1] M. Belewu, and O. Aiyegbusi, "Comparison of the mineral content and apparent biological value of milk from human, cow and goat." Journal of Food Technology in Africa, vol. 7, no.1, pp. 9-11, 2004.

[2] Z. Güler. "Levels of 24 minerals in local goat milk, its strained yoghurt and salted yoghurt (tuzlu yoğurt)." Small Ruminant Research, vol. 71, no.1, pp. 130-137, 2007.

http://dx.doi.org/10.1016/j.smallrumres.2006.05.011

[3] G. Z. Soliman. "Comparison of chemical and mineral content of milk from human, cow, buffalo, camel and goat in Egypt." Egypt J. Hosp. Med, vol. 21, pp. 116-130, 2005.

[4] E. Janle, J. Sojka, G. Jackson, P. Lachcik, J. Einstien, and C. Santerre. "Measuring transfer of $14 \mathrm{C}$-PCB from maternal diet to milk in a goat model using an accelerator mass spectrometer (AMS). Nuclear Instruments and Methods in Physics Research Section B:" Beam Interactions with Materials and Atoms, 259(1), pp. 758-762, 2007.

[5] J. M. Steijns. "Milk ingredients as nutraceuticals." International Journal of Dairy Technology, vol. 54, no.3, pp. 81-88, 2001. http://dx.doi.org/10.1046/j.1364-727x.2001.00019.x

[6] G. Singh, R. Sharma, and R. Mishra. "Seasonal Variations in the Milk Minerals of Jakhrana Goats under Field and Farm Rearing Conditions." Journal of Community Mobilization and Sustainable Development, vol. 9, no. 2, pp. 120-123, 2014.

[7] M. Boland. "The dairy product value chain: new opportunities from a holistic approach? Paper presented at the Proceedings-New Zealand Society of Animal Production. 2002.

[8] M. Sikirić, N. Brajenović, I. Pavlović, J. Havranek, and N. Plavljanić. "Determination of metals in cow's milk by flame atomic absorption spectrophotometry". Czech Journal of Animal Science, vo. 48, no. 11, pp. 481-486, 2003.

[9] Z. Antunovic, I. Bogut, D. Sencic, M. Katic, and P. Mijic. "Concentrations of selected toxic elements (cadmium, lead, mercury and arsenic) in ewe milk in dependence on lactation stage." Czech Journal of Animal Science, vo. 50, no. 8, pp. 376, 2005.

[10] D. Yurtsever Sarica, and A. R. Türker. "Method Validation for the Determination of Lead in Raw Cow's Milk Electrothermal Atomic Absorption Spectrometry." Annali di chimica, vol. 97, no.10, pp. 983993, 2007. http://dx.doi.org/10.1002/adic.200790100

[11] S. Birghila, S. Dobrinas, G. Stanciu, and A. Soceanu. "Determination of major and minor elements in milk through ICP-AES." Environmental engineering and management journal, vol. 7, no. 6, pp. 805-808, 2008. 